\title{
First endemic arachnid from Isla Sala y Gómez (Motu Motiro Hiva), Chile: a new species of tube-dwelling spider (Araneae: Segestriidae)
}

\author{
André Marsola GIROTI ${ }^{1}$, Darko D. COTORAS ${ }^{2, *}$, Pedro LAZO $^{3}$ \& \\ Antonio Domingos BRESCOVIT ${ }^{4}$ \\ ${ }^{1}$ Departamento de Zoologia, Instituto de Biociências, Universidade de São Paulo, \\ São Paulo, SP 05508-090, Brazil. \\ ${ }^{1,4}$ Laboratório Especial de Coleções Zoológicas, Instituto Butantan, \\ São Paulo, SP 05503-900, Brazil. \\ ${ }^{2}$ Entomology Department, California Academy of Sciences, 55 Music Concourse Dr., \\ Golden Gate Park, San Francisco, CA 94118, USA. \\ ${ }^{3}$ Corporación Nacional Forestal, Provincial Isla de Pascua, Chile. \\ *Corresponding author: darkocotoras@gmail.com \\ 1Email: giroti.am@usp.br \\ ${ }^{3}$ Email: pedro.lazo@conaf.cl \\ ${ }^{4}$ Email: antonio.brescovit@butantan.gov.br

\footnotetext{
${ }^{1}$ urn:1sid:zoobank.org:author:0F52E01E-A46C-43B0-ABB6-C10BD467CCC8

${ }^{2}$ urn:lsid:zoobank.org:author:3B80E04C-082B-4160-B9E8-34E601750E6F

${ }^{3}$ urn:1sid:zoobank.org:author:8839E0EE-A280-4069-B7E9-F6237CC304B6

${ }^{4}$ urn:1sid:zoobank.org:author:D5B81D79-AFAE-47B1-8A6E-DAB448A24BCC
}

\begin{abstract}
The Isla Sala y Gómez or Motu Motiro Hiva is located $415 \mathrm{~km}$ northeast of Rapa Nui (Easter Island) and $3420 \mathrm{~km}$ from the coast of northern Chile. It is a small oceanic island $\left(2.5 \mathrm{~km}^{2}\right)$ dominated by volcanic rock with very little vegetal cover. Here, we describe the first endemic arachnid for the island, Ariadna motumotirohiva sp. nov. Females are similar to those of Ariadna perkinsi Simon, 1900 from Hawai' $i$ and Ariadna lebronneci Berland, 1933 from the Marquesas in the dorsal dark abdominal pattern, but they differentiate from the latter in the anterior receptaculum, promarginal cheliceral teeth and leg IV macrosetae. A recent survey of the arachnid fauna of Rapa Nui, which included Motu Nui and the rocky shores, did not record the presence of the family Segestriidae, neither has it been found during previous surveys. However, it is not possible to discard the possibility of a local extinction on Rapa Nui and survival on Sala y Gómez. This study suggests other endemic terrestrial arthropods could be present on this very small and remote island.
\end{abstract}

Keywords. Taxonomy, Synspermiata, Ariadna, Pacific Islands, morphology.

Giroti A.M., Cotoras D.D., Lazo P. \& Brescovit A.D. 2020. First endemic arachnid from Isla Sala y Gómez (Motu Motiro Hiva), Chile: a new species of tube-dwelling spider (Araneae: Segestriidae). European Journal of Taxonomy 722: 97-105. https://doi.org/10.5852/ejt.2020.722.1137 


\section{Introduction}

Ariadna Audouin, 1826 is a genus in the tube-web family Segestriidae, currently comprising 107 species (World Spider Catalog 2019). Recently, Giroti \& Brescovit (2018) presented a new taxonomic revision of the genus for the American continent, in which six species were recorded from Chile: Ariadna maxima (Nicolet, 1849), A. abrilae, A. araucana, A. changellkuk, A. levii, all described by Grismado (2008), and A. lalen Giroti \& Brescovit, 2018. Currently, only A. maxima can be found on Chilean islands, most precisely on the Juan Fernández islands, a small archipelago near the Chilean coast. Similarly to other members of the Segestriidae, this genus inhabits silk tube-webs, with irradiate threads, often inside tree logs and bark, rock crevices, and human constructions (Giroti \& Brescovit 2018). Some species are even found in desert areas of Namibia, where they build silk tubes burrowed in the sand (Costa et al. 1995; Costa \& Conti 2013).

The Isla Sala y Gómez or Motu Motiro Hiva $\left(26^{\circ} 28^{\prime} \mathrm{S}, 105^{\circ} 21^{\prime} \mathrm{W}\right)$ is located $415 \mathrm{~km}$ northeast of Rapa Nui (Easter Island) and $3420 \mathrm{~km}$ from the coast of northern Chile. It is $2.5 \mathrm{~km}^{2}$ in area, has a horseshoe shape and measures $700 \mathrm{~m}$ east-west and $400 \mathrm{~m}$ north-south at its widest points (Fig. 1). The highest point reaches only $30 \mathrm{~m}$ above sea level (Castilla \& Oliva 1988). This volcanic island is part of the same underwater mountain chain as Rapa Nui. The age of its lava flows ranges between 1.31 and 1.94 million years (Clark \& Dymond 1977). The island's surface is dominated by volcanic rock with very little vegetal cover, composed of two vascular plants (Portulaca oleracea L. and Sesuvium portulacastrum (L.) L.; Rehder 1980) and one fern (Asplenium obliquum G.Forst.; Skottsberg 1956). Most of the faunistic studies from the island refer to marine invertebrates (Rehder 1980; Castilla \& Rozbaczylo 1988; Burukovsky 1990; Tabachnick 1990; Coloma et al. 2004) and fishes (Parin 1991; Pequeño 2004). There are also records for 14 species of sea birds, with 10 of those nesting on site (Vilina \& Gazitua 1999). The first record for a terrestrial arthropod on the island corresponded to Cryptamorpha desjardinsi (Guérin-Méneville, 1844) (Silvanidae, Coleoptera; see Elgueta \& Lazo 2013). This species is considered cosmopolitan and it is present on Rapa Nui (Campos \& Peña 1973). Recently, Hershauer et al.

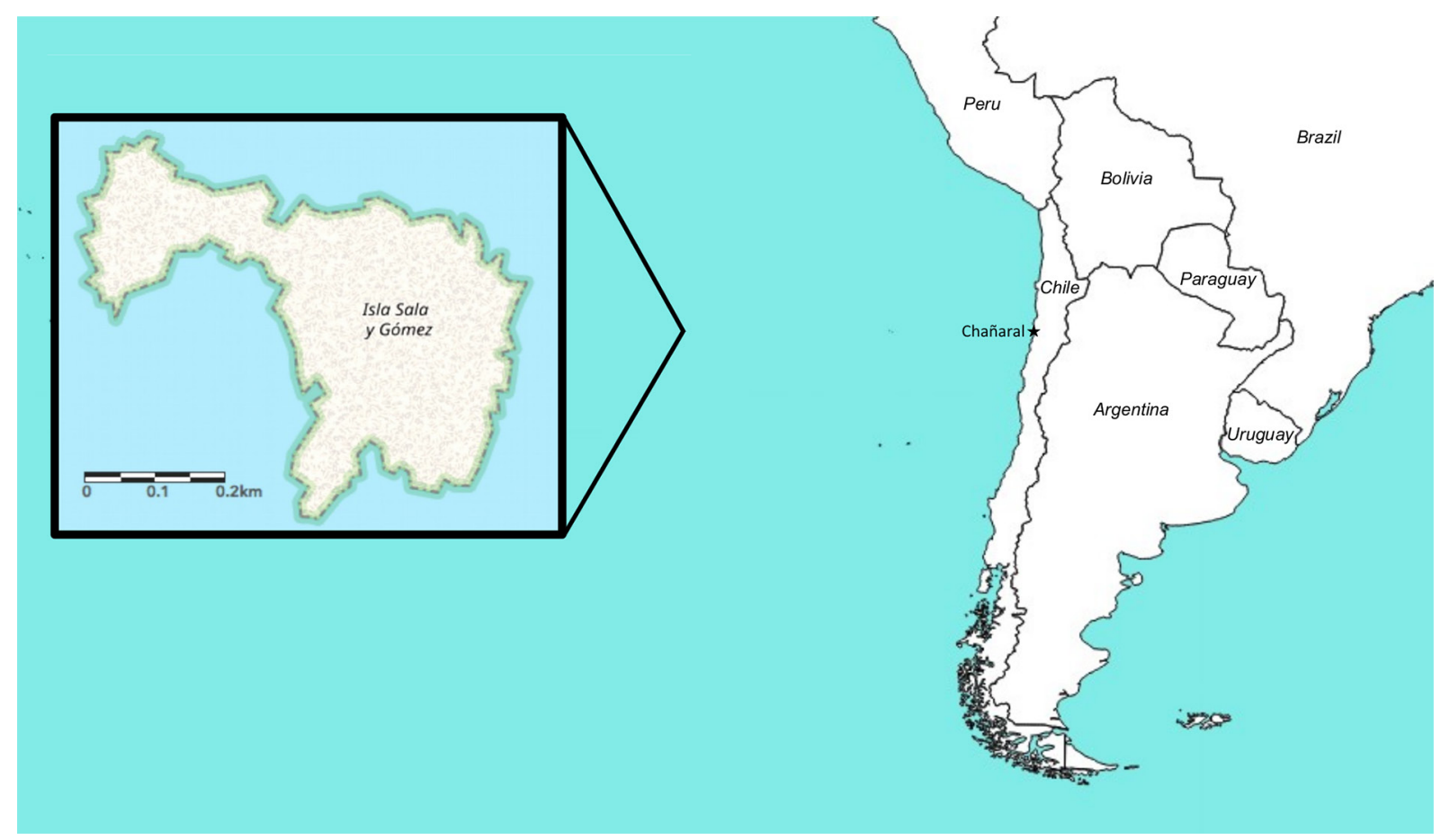

Fig. 1. Map of southern South America and Isla Sala y Gómez in detail. The islet is located approximately in front of Chañaral along the chilean coast. 
(2020) published an arthropod inventory carried out in 2016. In this species list, they report the presence of 15 terrestrial morphospecies representing 10 different orders, which include three arachnids including a Segentriidae, but without definition of species. The remoteness of Sala y Gómez, combined with the difficulties in accessing it are likely responsible for the limited number of terrestrial invertebrate records. In the present study, we describe the first endemic arachnid for the island, a new segestriid species, based on female specimens collected in 2012.

\title{
Material and methods
}

Examinations and descriptions of the specimens were made under a Leica MZ6 stereo microscope. Descriptions, macrosetae pattern and female internal genitalia preparation follow Giroti \& Brescovit (2018). Measurements are in millimeters (mm), except those of the internal female genitalia. External morphology photographs were taken with a Leica DFC 500 digital camera attached to a Leica MZ16A stereo microscope; extended focal range photos were composed with Leica Application Suite ver. 3.8. Internal female genitalia photographs were taken with a Leica DFC 425 digital camera attached to a Leica DM 2500 microscope and stacked using Combine ZP 1.0 software. Illustrations were made using a Leica DM 4000 B microscope with camera lucida attached. Geographical coordinates are given in degrees (DMS). The map on Fig. 1 was treated with Esri (www.esri.com) and QGIS (ver. 2.18.28).

\section{Abbreviations}

\begin{tabular}{|c|c|c|c|}
\hline ALS & $=$ anterior lateral spinnerets & $\mathrm{p}$ & $=$ prolateral \\
\hline AR & $=$ anterior receptaculum & PLS & $=$ posterior lateral spinnerets \\
\hline $\mathrm{d}$ & $=$ dorsal & PR & $=$ posterior receptaculum \\
\hline DL & $=$ dorsal lobe & $\mathrm{r}$ & $=$ retrolateral \\
\hline GD & $=$ glandular ducts plate & UE & $=$ uterus externus \\
\hline IBSP & $=$ Instituto Butantan São Paulo & $\mathrm{v}$ & $=$ ventral \\
\hline IF & $=$ interpumonary fold & VL & $=$ ventral lobe \\
\hline MNHN & $=$ Museo Nacional de Historia Natural de Chile & $\mathrm{vp}$ & $=$ ventro-prolateral \\
\hline & & $\mathrm{vr}$ & $=$ ventro-retrolateral \\
\hline
\end{tabular}

\section{Results}

\section{Taxonomy}

\author{
Class Arachnida Cuvier, 1812 \\ Order Araneae Clerck, 1757 \\ Family Segestriidae Simon, 1893 \\ Subfamily Ariadninae Wunderlich, 2004 \\ Genus Ariadna Audouin, 1826
}

Ariadna motumotirohiva sp. nov. urn:1sid:zoobank.org:act:BC432E25-E52D-4E0B-896D-0BDCE97BD2D4

Figs $1-3$

Segestriidae sp. - Hershauer et al. 2020: 3, fig. 3b.

\section{Diagnosis}

Females of Ariadna motumotirohiva sp. nov. are similar to those of Ariadna perkinsi Simon, 1900 and Ariadna lebronneci Berland, 1933 due to the dark dorsal abdominal pattern (Fig. 2A; Giroti \& Brescovit 2018: fig. 31a, e), but differ from the former by the anterior receptaculum with the dorsal lobe globous 
(Fig. 3; Giroti \& Brescovit, 2018: fig. 31i-j), by the presence of three promarginal teeth on the chelicerae and femur IV with dorsal macrosetae, and from the latter by four promarginal teeth (see Berland 1933: 44, figs 1-2).

\section{Etymology}

The name refers to the name given by the Rapa Nui people to the type locality, 'Motu Motiro Hiva'; noun in apposition.

\section{Type material}

\section{Holotype}

CHILE • + ; V Región de Valparaíso, Isla Sala y Gómez; 26²8’ S, 105²8’ W; Nov. 2012; P. Lazo leg.; MNHN (MNHN 8366).
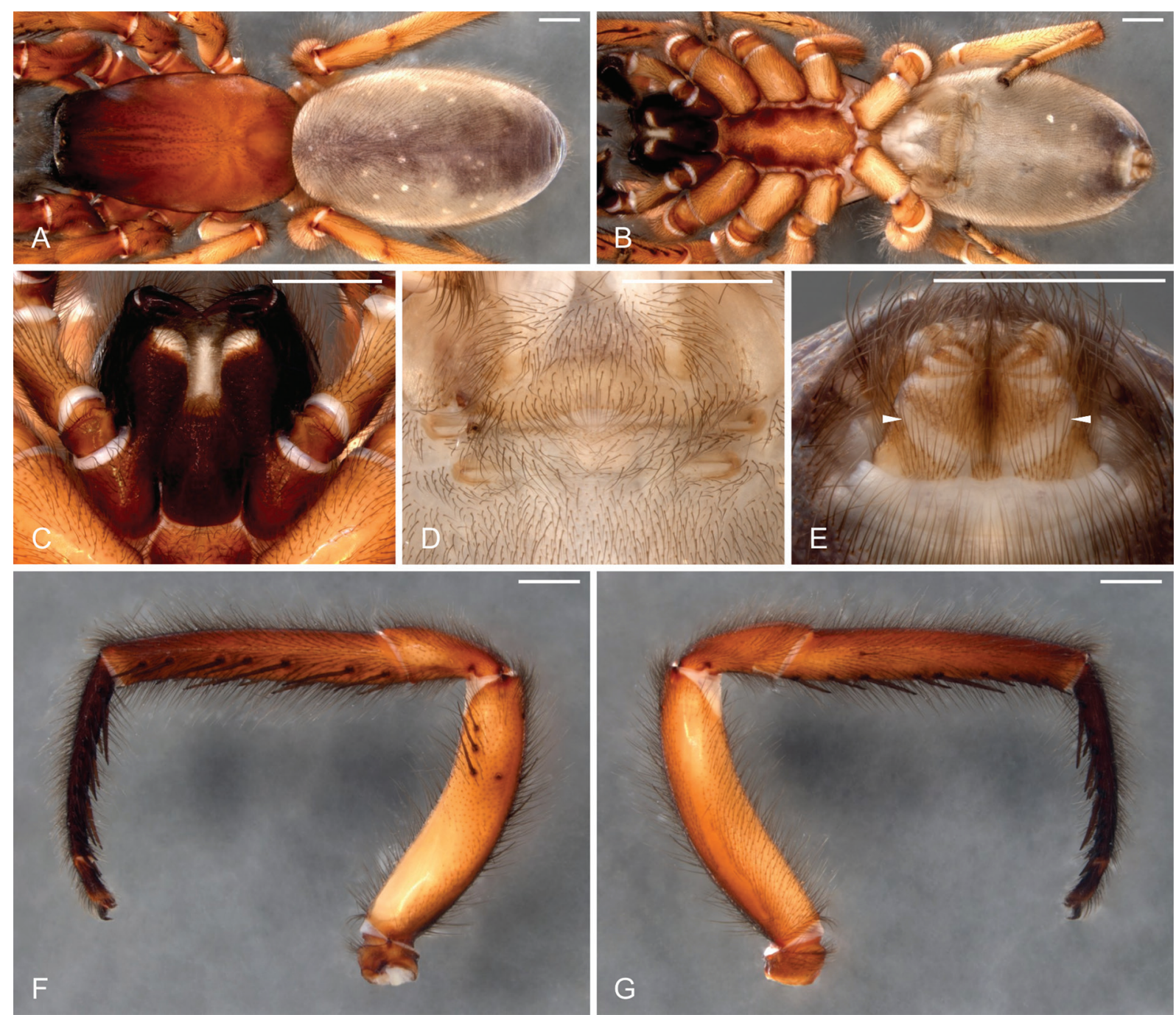

Fig. 2. Ariadna motumotirohiva sp. nov., + , holotype (MNHN 8366). A. Habitus, dorsal view. B. Habitus, ventral view. C. Endites, labium and labrum, ventral view. D. Epigastric furrow, ventral view. E. Spinnerets, ventral view, arrowheads showing the diagonal membranous stripes of the ALS. F. Right leg I, prolateral view. G. Right leg I, retrolateral view. Scale bars $=1 \mathrm{~mm}$. 


\section{Paratype}

CHILE • O ; V Región de Valparaíso; same collection data as for holotype; IBSP (IBSP 246895).

\section{Description}

Female (holotype) (measurements in $\mathrm{mm}$ )

Carapace orange with cephalic region reddish orange; eyes bounded by dark outlines (Fig. 2A). Chelicerae, endites and labium dark reddish orange (Fig. 2C). Sternum light orange with darker margins, and four pairs of dark marginal areas (Fig. 2B). Palps brownish orange, gradually darkening distally (Fig. 2B). Legs brownish orange with pairs I-II darker, and metatarsi and tarsi I-II reddish orange (Fig. $2 \mathrm{~F}-\mathrm{G}$ ). Abdomen whitish grey, with a fainted dark dorsal pattern comprising arrow-shaped marks (Fig. 2A-B). Total length 13.36; carapace 6.4 long, 3.76 wide. Carapace oblong, cephalic region narrower than thoracic region, with short setae conspicuously delimiting it. Six indirect eyes, with the posterior ones in a slightly recurved line (Fig. 2A). Chelicerae conical, wider basally, with frontal setae (Fig. 2A, C);
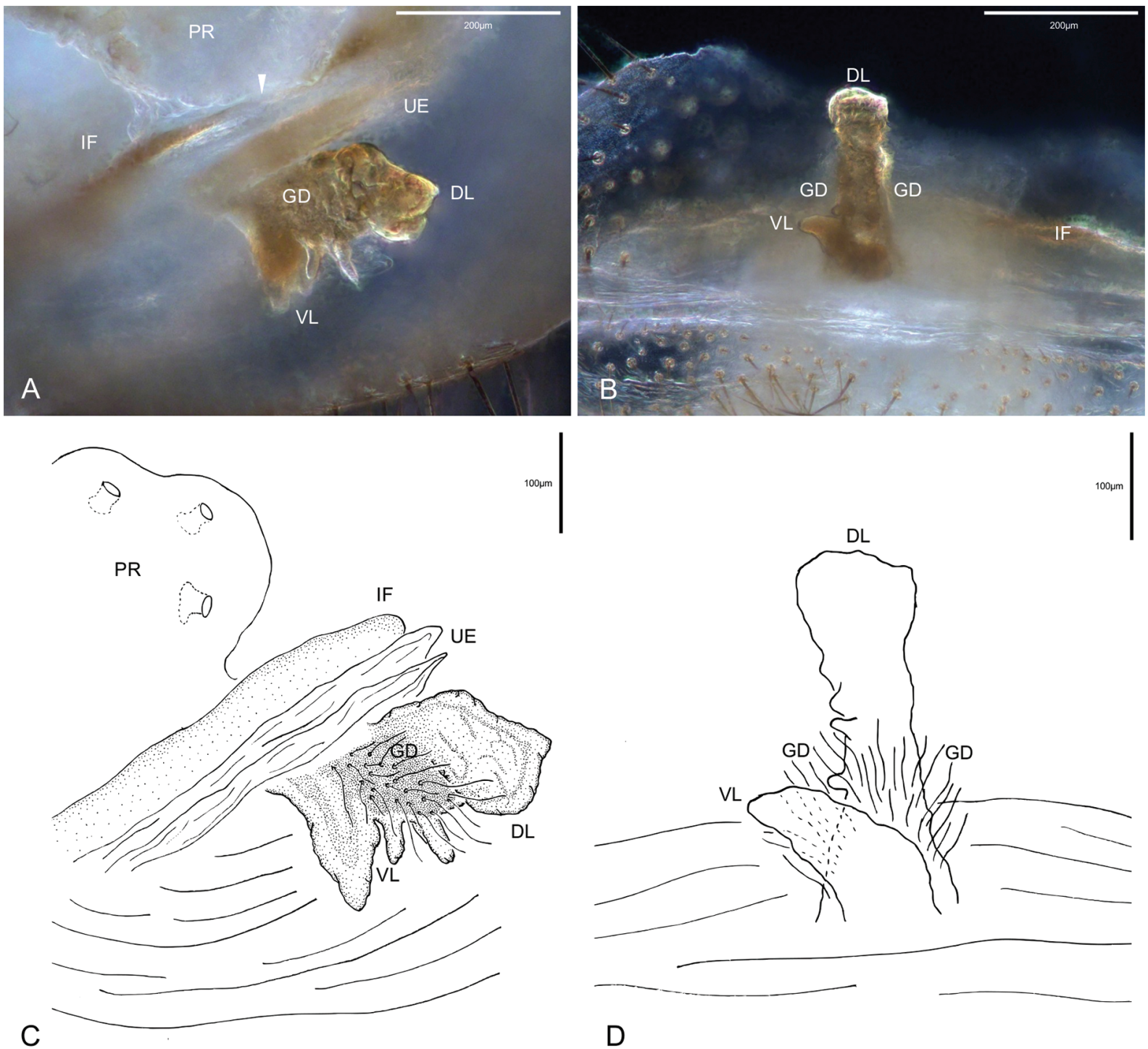

Fig. 3. Ariadna motumotirohiva sp. nov., $q$, paratype (IBSP 246895). A-D. Internal genitalia. A, C. Lateral view, arrowhead in A = median membranous crack. B, D. Detail of the anterior receptaculum, ventral view. 
chelicerae with one retromarginal and three promarginal teeth. Endites spatulate, narrowed medially, rounded distally and proximally. Labium longer than wide, with a narrowed distal region. Labrum well developed, longer than the labium (Fig. 2C). Palps short and robust, with one diaxially orientated articulated claw; tarsi and tibia with prolateral setae. Legs robust, pair III directed forward (Fig. 2A-B, F-G). Leg formula: I-IV-II-III. Leg measurements: I, femur 4.48, patella 2.2, tibia 4.4, metatarsus 3.32, tarsus 0.72 , total 15.12; II, 3.88, 2.08, 4.12, 3.04, 0.64, 13.76; III, 3.28, 1.76, 2.64, 2.52, 0.8, 11.0; IV, 4.32, 2.16, 3.6, 3.2, 0.8, 14.08. Macrosetae: I, femur d0-0-0-0-0-0/1-1-2/1-0, p0-0-0-0-1-2-1/0-1-0; tibia vp1-1-0-1/0-1-1-0-1-1-0, vr1-1-1-0-1-1-0-1-1-1-0, r0-0-1-0-0-0-0-0; metatarsus vp1-1-1-1-0/1-11-1-1-1-1-0/1-0/1-1, vr1-0-1-1-0-1-1-0-1-1-1-1; II, femur d0-0-1-1-1-2-0-2-0, p0-0-0-0-0-1-0-1-0; tibia p0-1-0-1/0-1/0-0-0-0-0-0, vp1-1-1-1-1/0-1-0-1/0-1-0, vr1/2-1-1-0-1-1-0-1-1/0-0/1-1-0, r0-0-0-1/0-1/0$0-0-0-0$; metatarsus vp1-1-1-0/1-1-1-1-1-1-1-1, vr1-0-1-1-0-1-0-1-1-0-1; IV, femur d0-1-1-1-0-1/0-1/0$0-0-0, \mathrm{r} 0-0-0-0-0-0-0-1-0-0$; metatarsus vr metatarsal comb with 3 macrosetae. Abdomen membranous, longer than wide, uniformly hairy; epigastric genital plate sclerotized; tracheal system dysderoid like, with the tracheal openings positioned near the epigastric furrow (Fig. 2A-B, D). Six spinnerets, ALS with three segments, the basal one crossed by a diagonal membranous band; PLS with distal external sclerite equally sclerotized; colulus distinct and pilose (Fig. 2E). Internal female genitalia with anterior receptaculum billobulated, dorsal lobe conspicuously longer than the ventral one, with median and ventral projections; glandular ducts plate medianly positioned; interpulmonary fold with the dorsal margin sclerotized, and a median membranous crack; posterior receptaculum membranous, with tubular invaginations (Fig. 3).

\section{Variation}

Female $(n=2)$ : total length 10.8-13.36; carapace 5.92-6.4 long, 3.44-3.76 wide; femur I 3.76-4.48.

\section{Note}

For comparison we used the female specimen of $A$. perkinsi described by Giroti \& Brescovit (2018) (IBSP 209056) and the original description and illustrations provided by Berland (1933: 44) of A. lebronneci.

\section{Distribution}

Only known from the type locality (Fig. 1).

\section{Discussion}

A new species from the family Segestriidae is described based on female specimens collected on the remote Isla Sala y Gómez. The species is most similar to Ariadna perkinsi Simon, 1900 and Ariadna lebronneci Berland, 1933 due to the dorsal dark abdominal pattern; however, it differentiates from them in the anterior receptaculum and the promarginal cheliceral teeth, and leg IV macrosetae, respectively. These morphological affinities suggest an evolutionary proximity; however, explicit phylogenetic reconstructions including this species are still needed.

The colonization by the genus Ariadna of several remote archipelagos in the eastern Pacific (A. perkinsi in Hawai' ${ }^{\prime}$, A. lebronneci in the Marquesas, A. maxima in the Juan Fernández, A. tarsalis in the Galápagos, and $A$. weaveri in the Revillagigedo Islands; Grismado 2008; Giroti \& Brescovit 2018; World Spider Catalog 2019), may have been mediated by rafting. The large size of these spiders when adult probably prevents mature specimens from performing ballooning (see Sheldon et al. 2017), although there is an exception to this claim found in Eresidae (Schneider et al. 2001). Currently, a single species is described for each group of islands, implying that the genus is not prone to diversifying within an island, or that there are cryptic species yet to be described. 
Ariadna motumotirohiva sp. nov. is present on a single island, the closest land mass is Rapa Nui at $415 \mathrm{~km}$. This distance is about $50 \mathrm{~km}$ greater than the separation between Kaua' $i$ and Maui in Hawai' $i$, or Isla Darwin and Isla San Cristóbal in the Galápagos; each island pair having populations of the respective species from the archipelago (Giroti \& Brescovit 2018). However, there is the important difference of only having water between Sala y Gómez and Rapa Nui; while for the other examples, there are other islands in between, facilitating a potential stepping stone dispersal. Because of the high number of terrestrial extinctions on Rapa Nui (Wynne et al. 2014), the lack of knowledge and the depopulate condition of Sala y Gómez, it is difficult to argue that both islands correspond to an archipelago system, although for marine organisms this idea has been suggested (Rehder 1980). For this reason, the marine environment of Sala y Gómez might resemble the one on Rapa Nui before humans. Does the same situation apply to the terrestrial environment? It is important to consider the intrinsic particularities of Sala y Gómez, which create strong constraints for the species that inhabit it; particularly, the lack of permanent sources of fresh water, the reduced vegetation and the complete exposure to the marine environment. Therefore, the fairest comparison with Rapa Nui will correspond to the rocky shores or, even more similarly, to the two islets on the south of the island (Motu Nui and Motu Iti).

A recent survey of the arachnid fauna of Rapa Nui, which included Motu Nui and the rocky shores, did not record the presence of Segestriidae, neither was it described from previous collections (Cotoras et al. 2017a). However, it is not possible to discard the possibility of local extinction on Rapa Nui and survival on Sala y Gómez. The only endemic spider described for Rapa Nui, Tetragnatha paschae (Tetragnathidae), potentially went extinct during the first half of the $20^{\text {th }}$ century (Cotoras et al. 2017b), implying that other unrecorded extinctions may also have occurred.

Neighboring small islets could function as relictual sites for the species originally present on the main island. This has been shown for plants in Hawai' $\mathrm{i}$ (Wood 2012) and for the Lord Howe Island stick insect (Priddel et al. 2003). The situation of the latter bears similarities to that of A. motumotirohiva sp. nov., due to the almost complete lack of vegetation on Ball's pyramid, the islet where the stick insect was re-discovered.

This study provides the first record of an endemic arachnid on Isla Sala y Gómez, suggesting that other endemic terrestrial arthropods could be present on this very small and remote island. Only paleontological studies of sediment cores from the Rapa Nui lakes could reveal whether A. motumotirohiva sp. nov. is a relictual species previously also present on Rapa Nui or an extreme case of local insular endemism.

\section{Acknowledgments}

The specimens of A. motumotirohiva sp. nov. were collected by Pedro Lazo. We appreciate the support of CONAF and Parque Nacional Rapa Nui. The transportation to the island was possible thanks to the logistic support of the Armada de Chile. We would like to thank the financial support of FAPESP (grants to AMG: 2011/03016-0 and 2013/23801-6; grant to ADB: 2011/50689-0) and CNPq (grant to ADB: 303903/20019-8 ). DDC was supported with personal funds.

\section{References}

Audouin V. 1826. Explication sommaire des planches d'arachnides de l'Egypte et de la Syrie. In: Description de l'Egypte, ou recueil des observations et des recherches qui ont été faites en Égypte pendant l'expédition de l'armée française, publié par les ordres de sa Majesté l'Empereur Napoléon le Grand. Histoire Naturelle 1 (4): 1-339 (arachnids, pp. 99-186).

Berland L. 1933. Araignées des Iles Marquises. Bernice P. Bishop Museum Bulletin 114: 39-70.

Burukovsky R.N. 1990. Shrimps from the Sala y Gómez and Nazca Ridges. Trudy Acta Okeanologyi 124: 187-217. 
Campos S.L. \& Peña G.L.E. 1973. Los insectos de la isla de Pascua (Resultados de una prospección entomológica). Revista Chilena de Entomología 7: 217-229.

Castilla J. \& Oliva D. 1988. Oceánicas Chilenas: Aspectos descriptivos y potencialidades. In: Castilla J.C. (ed.) Islas Oceánicas chilenas. Conocimiento Científico y necesidades de investigación: 15-35. Ediciones Universidad Católica de Chile.

Castilla J. \& Rozbaczylo N. 1988. Islas Invertebrados marinos de isla de Pascua y Salas y Gómez. In: Castilla J.C. (ed.) Islas Oceánicas chilenas. Conocimiento Cientifico y necesidades de investigación: 191-216. Ediciones Universidad Católica de Chile.

Clark J. \& Dymond J. 1977. Geochronology and petrochemistry of Easter and Sala y Gómez islands: implications for the Origin of Sala y Gómez ridge. Journal of Volcanology and Geothermal Research 2: 29-48. https://doi.org/10.1016/0377-0273(77)90014-2

Coloma C., Moyano H.I., Ruiz V.H. \& Marchant M. 2004. Moluscos litorales de Isla de Pascua, Chile, Recolectados por la Expedición CIMAR 5 - Islas Oceánicas I. Ciencia y Tecnología del Mar 27: 79-94.

Costa G. \& Conti E. 2013. Opening and closing burrows by the Namibian spider Ariadna sp. (Araneae: Segestriidae) in a year of heavy rainfall. The Journal of Arachnology 41: 215-218.

https://doi.org/10.1636/Hi13-04.1

Costa G., Petralia A., Conti E. \& Hänel C. 1995. A 'mathematical' spider living on gravel plains of the Namib desert. Journal of Arid Environments 29: 485-494.

https://doi.org/10.1016/S0140-1963(95)80020-4

Cotoras D.D., Murray G.G.R., Kapp J., Gillespie R.G., Griswold C., Simison W.S., Green R.E. \& Shapiro B. 2017a. Ancient DNA resolves the history of Tetragnatha (Araneae, Tetragnathidae) spiders on Rapa Nui. Genes 8: 403. https://doi.org/10.3390/genes8120403

Cotoras D.D., Wynne J.J., Flores-Prado L. \& Villagra C. 2017b. The spiders of Rapa Nui (Easter island) revisited. Bishop Museum Occasional Papers 120: 1-17.

Elgueta M. \& Lazo P.H. 2013. Cryptamorpha desjardinsi (Guérin-Méneville, 1844) primer registro de un insecto (Coleoptera: Silvabidae) para la Isla Sala y Gómez, Chile. Acta entomológica chilena 33: $63-66$.

Giroti A.M. \& Brescovit A.D. 2018. The taxonomy of the American Ariadna Audouin (Araneae: Synspermiata: Segestriidae). Zootaxa 4400: 1-114. https://doi.org/10.11646/zootaxa.4400.1.1

Grismado C.J. 2008. A taxonomic revision of the spider genus Ariadna Audouin, 1826 in Argentina and Chile, with the description of five new species (Arachnida, Araneae, Segestriidae). Zoosystema 30 (2): 333-360.

Hershauer S.N., Yancovic Pakarati S. \& Wynne J.J. 2020. Notes on the arthropod fauna of Salas y Gómez island, Chile. Revista Chilena de Historia Natural 93 (4): 1-6.

https://doi.org/10.1186/s40693-020-00093-w

Nicolet A.C. 1849. Aracnidos. In: Gay C. (ed.) Historia física y politica de Chile. Zoología 3: 319-543.

Parin N.V. 1991. Fish fauna of the Nazca and Sala y Gomez submarine ridges, the easternmost outpost of the Indo-West Pacific zoogeographic region. Bulletin of Marine Science 49: 671-683.

Pequeño G.R. 2004. Peces litorales de la Isla Salas y Gómez, Chile, capturados durante el crucero CIMAR-ISLAS, en 1999. Ciencia y Tecnología del Mar 27: 95-101. 
Priddel D., Carlile N., Humphrey M., Fellenberg S. \& Hiscox D. 2003. Rediscovery of the 'extinct' Lord Howe Island stick insect (Dryococelus australis (Montrouzier)) (Phasmatodea) and recommendations for its conservation. Biodiversity and Conservation 12: 1391-1403.

https://doi.org/10.1023/A:1023625710011

Rehder H.A. 1980. The marine mollusks of Easter Island (Isla de Pascua) and Salas y Gómez. Smithsonian Contributions to Zoology 289: 1-167. https://doi.org/10.5479/si.00810282.289

Schneider J.M., Roos J., Lubin Y. \& Henschel J.R. 2001. Dispersal of Stegodyphus dumicola (Araneae, Eresidae): they do balloon after all!. The Journal of Arachnology 29: 114-116.

https://doi.org/10.1636/0161-8202(2001)029[0114:dosdae]2.0.co;2

Sheldon K.S., Zhao L., Chuang A., Panayotova I.N., Miller L.A. \& Bourouiba L. 2017. Revisiting the physics of spider ballooning. In: Layton A. \& Miller L. (eds) Women in Mathematical Biology. Association for Women in Mathematics Series, vol. 8. Springer, Cham.

Simon E. 1893. Histoire naturelle das araignées 1: 257-488. Paris.

Skottsberg C. 1956. Derivation of the flora and fauna of Juan Fernandez and Easter Island. In: Skottsberg C. (ed.) The Natural History of the Juan Fernandez and Easter Islands, vol. 1 (Botany): 193-405. Almqvist \& Wiksell, Uppsala.

Tabachnick K.R. 1990. Hexactinellid sponges from the Nazca and Sala y Gómez Ridges. Trudy Instituta Okeanologii AN USSR 124: 161-173.

Vilina Y.A. \& Gazitua F.J. 1999. The birds of Sala y Gomez Island, Chile. Waterbirds: The International Journal of Waterbird Biology 22: 459-462. https://doi.org/10.2307/1522124

Wood K.R. 2012. Possible extinctions, rediscoveries, and new plant records within the Hawaiian Islands. Bishop Museum Occasional Papers 113: 91-102.

World Spider Catalog. 2019. World Spider Catalog. Natural History Museum Bern, version 19.0.

Avaliable from http://wsc.nmbe.ch/ [accessed on 4 Jun. 2019].

Wunderlich J. 2004. Fossil spiders (Araneae) of the superfamily Dysderoidea in Baltic and Dominican amber, with revised family diagnoses. Beiträge zur Araneologie 3: 633-746.

Wynne J.J., Bernard E.C., Howarth F.G., Sommer S., Soto-Adames F., Taiti S., Mockford E.L., Horrocks M., Pakarati L. \& Pakarati-Hotus V. 2014. Disturbance relicts in a rapidly changing world: the Rapa Nui (Easter Island) factor. BioScience 64: 711-718. https://doi.org/10.1093/biosci/biu090

Manuscript received: 4 June 2019

Manuscript accepted: 27 July 2020

Published on: 30 October 2020

Topic editor: Rudy Jocqué

Desk editor: Connie Baak

Printed versions of all papers are also deposited in the libraries of the institutes that are members of the EJT consortium: Muséum national d'histoire naturelle, Paris, France; Meise Botanic Garden, Belgium; Royal Museum for Central Africa, Tervuren, Belgium; Royal Belgian Institute of Natural Sciences, Brussels, Belgium; Natural History Museum of Denmark, Copenhagen, Denmark; Naturalis Biodiversity Center, Leiden, the Netherlands; Museo Nacional de Ciencias Naturales-CSIC, Madrid, Spain; Real Jardín Botánico de Madrid CSIC, Spain; Zoological Research Museum Alexander Koenig, Bonn, Germany; National Museum, Prague, Czech Republic. 